\title{
Disaster and New Adaptations: Digital Transformation in Public Services as an impact of the COVID-19 Pandemic in Indonesia
}

\author{
Amni Zarkasyi Rahman ${ }^{1}$, Retna Hanani ${ }^{2}$, Hardi Warsono ${ }^{3}$, Retno Sunu Astuti ${ }^{4}$, Ika Riswanti \\ Putranti $^{5}$ \\ \{amni.rahman@live.undip.ac.id ${ }^{1}$, r.hanani@live.undip.ac.id ${ }^{2}$, hardie_wsn@live.undip.ac.id ${ }^{3}$, \\ retnosunu@gmail.com ${ }^{4}$, ikarisp@gmail.com $\left.{ }^{5}\right\}$ \\ Diponegoro University, Indonesia ${ }^{1}$, Diponegoro University, Indonesia ${ }^{2}$, Diponegoro University, \\ Indonesia $^{3}$, Diponegoro University, Indonesia ${ }^{4}$, Diponegoro University, Indonesia ${ }^{5}$
}

\begin{abstract}
Public services in Indonesia have changed drastically due to COVID-19 Pandemic. However, the digitalization of public services has started to become a new trend as part of innovation. Many institutions improvise in providing public services by improving existing electronic-based public services. This study aims to describe the various digital transformation forms of public services and the main factors influencing success. This factor is the technological infrastructure that supports the implementation of electronic-based public services. Thus, this paper shows that digital transformation is strongly influenced by the availability of applications and social media that are forced to accommodate various online routines, including the provision of public services.
\end{abstract}

Keywords: Public Service; Digital Transformation; Technological Infrastructure.

\section{Introduction}

Public services transformation is underway in Indonesia. Formally, the transformation process can be seen from several regulations about public services and bureaucratic reform, including Law Number 25 of 2009 about Public Services, Presidential Regulation Number 81 of 2010 on the Grand Design of Bureaucratic Reform 2010-2025, and the Regulation of the Ministry of Administrative and Bureaucratic Reform Number 26 of 2020 on Guidelines for Evaluating the Implementation of Bureaucratic Reform. These regulations become set of guideline for public service innovation, improving quality of services, and transforming Indonesian bureaucracy at macro level. In this context, data shows that there is an increasing trend in the accountability of the national government from 2015-2019 (Fig.1). 


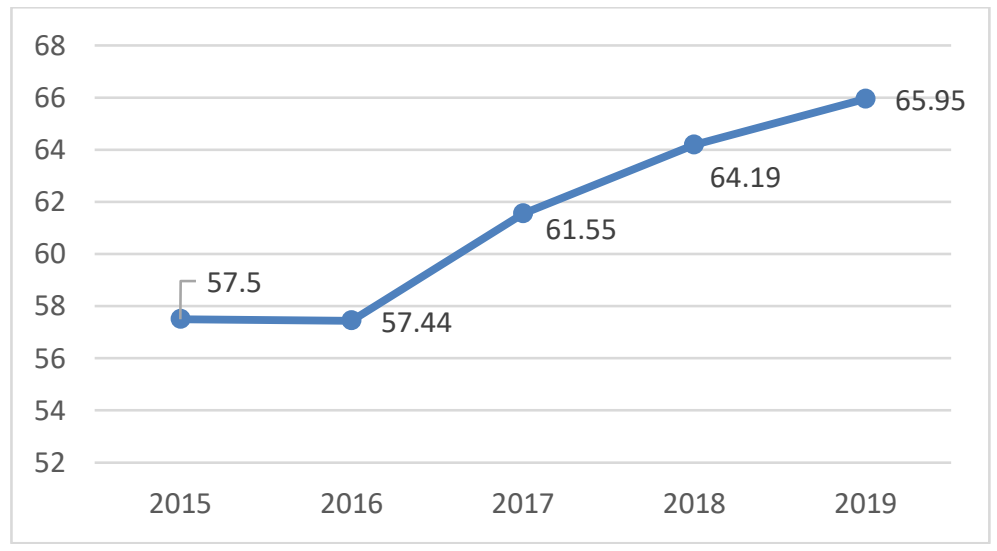

Fig. 1 Accountability Score of Government Performance 2015-2019 [2]

One important part of the transformation is the implementation of e-government implementation at the central and local governments [1]. In this paper, we argue that the transformation of Indonesian bureaucracy cannot be separated from digital transformation in the bureaucratic structure. This effort requires supports of an electronic-based government system with a scope covering e-planning, e-procurement, e-budgeting, and e-service. In Indonesia, implementation of e-government is manifested in Presidential Regulation Number 95 of 2018 about Electronic-Based Government Systems (SPBE). Digitizing public services governance will ensure transparency and cut bureaucratic flows to speed up the service process. If we look at the national electronic-based government system index score, we can see that there is an increasing trend of digitalization in Indonesia bureaucracy. Data from the United Nations (UN) e-Government Survey 2020 [3] also places Indonesia in the 88th rank of developing and implement e-government or electronic-based government systems (SPBE). The results for 2020, released in July, shows an increase of 19 rankings compared to 2018, which was in 107th place and 116th in 2016.

In addition, UN e-Government Survey data shows Indonesia achieves a score of 0.6612 in the High e-Government Development Index (EGDI) group in the 2020. The score places Indonesia in the top 100 world rankings as number 88 out of 193 countries. The United Nations (UN) predicts countries that score more than 0.75 as Very High EGDI, for points 0.50 to 0.75 as High EGDI, points 0.25 to 0.50 as Middle EGDI, and less than 0.25 as Low EGDI. The measurement is important as it includes three dimensions of performance measurements in EGDI, including the online service index (OSI), the telecommunication infrastructure index (TII), and the human capital index (HCI). 


\begin{tabular}{|c|c|c|}
\hline Country Selector & \multicolumn{2}{|l|}{ Indonesia } \\
\hline ntrv I & Website & National Portal \\
\hline & Region & Asio \\
\hline Colot conta & Sub-Region & South-eastem Asia \\
\hline ountry & Income ${ }^{*}$ & Lower middle income \\
\hline & Income Value & $\begin{array}{l}3.540 \\
\text { USD. GNi per capita }\end{array}$ \\
\hline & Population & $258,162,113$ \\
\hline & E-Government Development Index & $\begin{array}{l}0.6612 \\
\text { Rank } 88 \text { of } 193\end{array}$ \\
\hline & E-Participation Index & $\begin{array}{l}0.7500 \\
\text { Rank } 57 \text { of } 193\end{array}$ \\
\hline
\end{tabular}

Fig. 2 UN e-Government for Indonesia [3]

In each of these performance measurement assessments, Indonesia recorded good scores, including an OSI score of 0.6824 , a TII score of 0.5669 , and an HCI score of 0.7342 . The three components are already above average of the world score. However, Indonesia is still below the regional average for the telecommunication infrastructure index score or TII when viewed from the Sub-Regional Asia Regional and Southeast Asia group. Furthermore, Indonesia managed to jump 35 places in the e-Participation Index in 2020, from previously being ranked 92 in 2018 to being ranked 53 in 2020 with a score of 0.7500 . This score is already above the world average with a score of 0.5677 , above the Asian Regional average with a score of 0.6294 . Above the Southeast Asia Regional average with a score of 0.6126. This makes Indonesia increase its predicate from previously included in the High Electronic Participation Index group to the Very High Electronic Participation Index Group.

Amid the achievement, the world conditions faced by the COVID-19 Pandemic require new adaptation in the public services delivery [4]. Many government policies to prevent this virus's spread have been issued and impacting public service standards implemented by service providers. Increasing public service standards will be one of the efforts to prevent the spread of this virus. Here are some of the policies implemented by service providers in order to to improve services during the pandemic COVID-19. The policies are 1) Providing Clear Information Regarding Service Standards; 2) Improve the Online Service Delivery System; 3) Adaptation of Facilities, Infrastructure, and Service Facilities; and 4) Increasing the competence of service providers [5].

Some of these policies will be implemented if service providers have the capacity to implement digital transformation. Digital transformation can change the relationship between service users and service providers [6], which previously interacted directly to indirectly through smartphones or other gadgets. However, service providers must be able to increase their digital maturity so that they are more flexible in preparing local needs-based service change plans [7].

Seeing the trend of online services as a form of the digital transformation of public services in Indonesia during the Pandemic, the question is what are factors that shape the relatively fast 
digital transformation. This research will describe the various factors that influence digital transformation in Indonesia during the COVID-19 Pandemic.

\section{Methodology}

Digital transformation is a particular case that can be influenced by several factors. This study used a qualitative descriptive research method with a case study strategy [8]. In this research we present a case study to illustrate the digital transformation of public services during the COVID-19 Pandemic in Indonesia. Researchers use Instagram as the primary data source to see the use of hashtags (\#) that indicates public services transformation through online-based services in Indonesia. Instagram was chosen because it can communicate images better with the use of hashtags (\#), which indicate a relationship with a particular topic [9], [10]. Furthermore, data collection uses literature reviews, and news analysis based on official local and national news portals. We look at factors that influences digital transformation in public services during the COVID-19 Pandemic.

\section{Finding and Discussion}

\subsection{Result}

To find out the implementation of online services, we look at online service hashtags (\#pelayananonline) on Instagram. Instagram was chosen because it is one of the social media with the highest user growth rate in Indonesia [11]. If you look at the total hashtags, it is known that \#pelayananonline was posted 549 times. Meanwhile, for some posts with \#pelayananonline, $27 \%$ of the total posts added \#dirumahaja, and $19 \%$ of total posts \# lawancovid19. This can be seen in the following figure:

\begin{tabular}{|c|c|c|c|}
\hline Hashtag Name & Hashtag Popularity & $\begin{array}{l}\text { \# Posts Found } \\
\text { with a given hashtag }\end{array}$ & $\begin{array}{l}\% \text { Usage } \\
\text { of total post }\end{array}$ \\
\hline \#pelayananonline & 549 & 452 & $100 \%$ \\
\hline \#dirumahaja & $15,970,568$ & 121 & $27 \%=$ \\
\hline \#lawancovid19 & 959,734 & 87 & $19 \%=$ \\
\hline
\end{tabular}



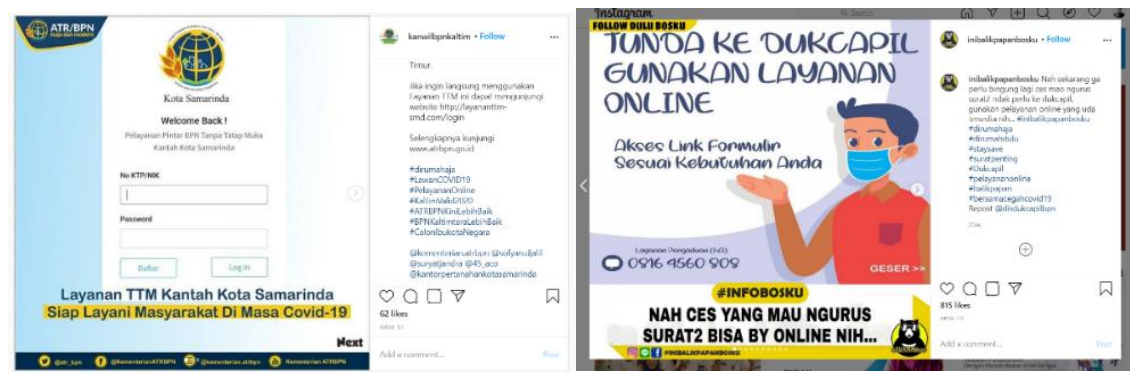

Fig. 3 sample of \#pelayananonline, \#dirumahaja, and \#lawancovid19 on Instagram

Based on the research results using Virol to processing hashtags that reflect the application of online services, it appears that online services are being carried out massively due to the COVID-19 Pandemic. Virol is a tool/browser extension that makes it easy to manage Instagram accounts by analyzing posting hours, number of hashtags/posts, and performance. This is evidenced by the addition of hashtags, namely \#dirumahaja and \#lawancovid19, as shown in Figure 3. Some service providers post directly about providing online services or are reposted by local-based information accounts. Some posts show that service providers are trying to provide online services even though with minimum readiness. This can be seen from the increasing number of mention of the admin contact number being contacted for the online service process.

Meanwhile, the number of \#pelayananonline posts based on time and day can be seen in the following figure:
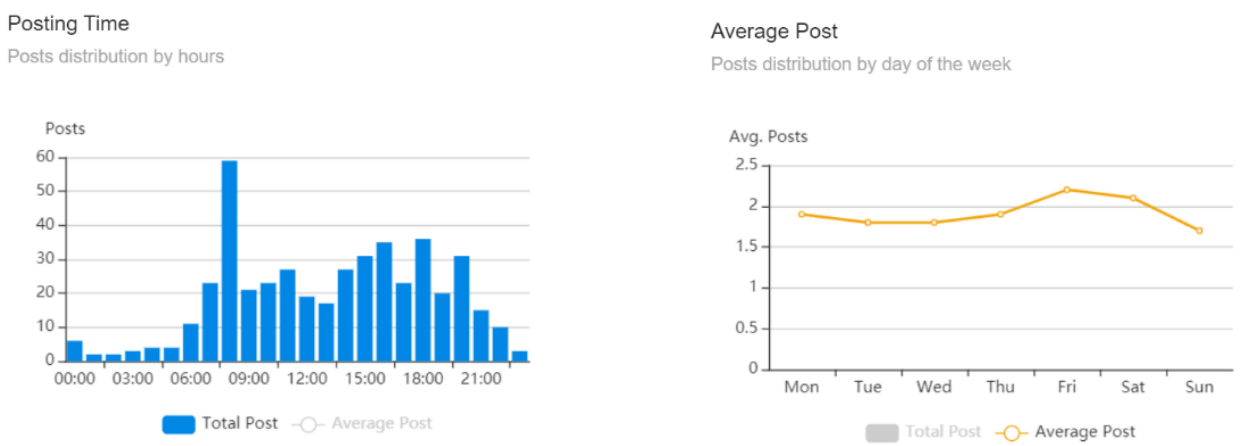

Fig. 4 Posting Time and Average Post of \#pelayananonline on Instagram

Based on Figure 4, it is known that the number of posts about online services was mostly made between $08.00-09.00$ hours. This marks the time when public services begin to open. From the average number of posts in one week, it is known that there are two posts per day about online services on average.

\subsection{Discussion}

Digital Transformation and Pandemic COVID-19

Coronavirus disease 2019 (COVID-19), which emerged at the end of 2019, has spread worldwide. The latest data has confirmed as many as 1,439,519 cases worldwide, with the death toll reaching 85,771 people (data on April 10 2020) [12]. This number is expected to increase 
due to the very high spread rate due to accelerating global urbanization, increasing population concentrations, more frequent and complex interactions, and lack of medical protection in developing countries [13]. This disease is similar to several previous infectious diseases that spread in the early 21st century, namely SARS (Severe Acute Respiratory Syndrome) and the Middle East Respiratory Syndrome Coronavirus (MERS-CoV) [14].

Indonesia has issued several policies to mitigate the spread of covid-19, including policies issued by the central government and local governments [15]. One of the policies that have received enough attention is large-scale social restrictions (PSBB), which are implemented based on Government Regulation Number 21 of 2020 about Large-Scale Social Restrictions (PSBB) Accelerating the Management of Corona Virus Disease. 2019 (COVID-I9). Based on this regulation, regions are required to close all activities within a certain period, including public service providers. After that, the public service provider unit began to operate on a limited basis by eliminating the direct service. Therefore, all public service units carry out digital transformation to continue providing basic services to the public. Many public service providers do not feel ready, and the transformation process is gradual. This can be seen from the service provider unit that provides a contact person who can be contacted to accommodate public service requests with WhatsApp (multi-platform messaging application).

Several service provider units that have already existed in online services have expanded their service reach by conducting various socialization through social media by providing hashtags to make them easy to find. The hashtags used include \#pelayananonline and \#pelayananpublik. Some of these service units have also made changes and adjustments to existing public service applications to make it easier for the public. An example is the SAKPOLE application, which is an android based application. The Online Tax Vehicle Administration System (SAKPOLE) is an electronic network service organized by the Central Java Province Samsat Advisory Team, based on the laws and regulations of the Republic of Indonesia regarding online SAMSAT services (e-SAMSAT). The SAKPOLE update on May 18,2020 , provides additional eSKPD download facilities and e-validation status notifications. Through this additional facility, applicants do not need to go to the Samsat office to get a Regional Tax Assessment (SKPD) because they can print themselves and pass electronically.

\section{Conclusion}

The Covid-19 Pandemic makes digital transformation in public services run faster so that services are not interrupted. Although it is being carried out in stages, this is a step forward that should be appreciated. For institutions that previously provided online services, both web-based and application-based, they will have more flexibility in making updates, such as printing service results independently. However, for institutions that do not yet provide online services, a digital transformation begins by providing a contact person who is accessed via WhatsApp. Therefore, the COVID-19 Pandemic can be used as the first step in implementing an ElectronicBased Government System (SPBE) effectively and efficiently. 


\section{References}

[1] R. Rihandoyo and A. Z. Rahman, "Evaluasi Keselarasan Kebijakan Pembanguan Electronic Government Antara Pemerintah Pusat, Provinsi Jawa Tengah, Dan Kabupaten/Kota (Kota Tegal Dan Kabupaten Batang)," Jurnal Ilmu Sosial, vol. 13, pp. 45-50, 2016.

[2] Katadata. Akuntabilitas Kinerja Pemerintah Terus Membaik dari Tahun ke Tahun [Online]. Available: https://databoks.katadata.co.id/datapublish/2020/10/01/ akuntabilitas-kinerja-pemerintah-terus-membaik-dari-tahun-ke-tahun\#

[3] U. Nations, United Nations E-Government Surveys: 2020 Digital Government in the Decade of Action for Sustainable Development. New York: United Nations, 2020.

[4] P. K. Senyo, J. Effah, and E. L. C. Osabutey, "Digital platformisation as public sector transformation strategy: A case of Ghana's paperless port," Technological Forecasting and Social Change, vol. 162, p. 120387, 2021/01/01/ 2021.

[5] Ombudsman. (2020). Peningkatan Standar Pelayanan Publik Di Tengah Pandemi Corona. Available: https://ombudsman.go.id/artikel/r/artikel--peningkatan-standarpelayanan-publik-di-tengah-pandemi-corona

[6] F. Zaoui and N. Souissi, "Roadmap for digital transformation: A literature review," Procedia Computer Science, vol. 175, pp. 621-628, 2020/01/01/ 2020.

[7] G. Fletcher and M. Griffiths, "Digital transformation during a lockdown," International Journal of Information Management, p. 102185, 2020/07/03/ 2020.

[8] J. W. Creswell and J. D. Creswell, Research design: Qualitative, quantitative, and mixed methods approaches: Sage publications, 2017.

[9] J. Klostermann, A. Plumeyer, D. Böger, and R. Decker, "Extracting brand information from social networks: Integrating image, text, and social tagging data," International Journal of Research in Marketing, vol. 35, pp. 538-556, 2018/12/01/ 2018.

[10] A. Arora, S. Bansal, C. Kandpal, R. Aswani, and Y. Dwivedi, "Measuring social media influencer index- insights from facebook, Twitter and Instagram," Journal of Retailing and Consumer Services, vol. 49, pp. 86-101, 2019/07/01/ 2019.

[11] W. K. Pertiwi. (2019). Sebanyak Inikah Jumlah Pengguna Instagram di Indonesia? Available: https://tekno.kompas.com/read/2019/12/23/14020057/sebanyak-inikahjumlah-pengguna-instagram-di-indonesia

[12] WHO. (2020, April 10). Available: https://who.sprinklr.com/

[13] C. Zhou, F. Su, T. Pei, A. Zhang, Y. Du, B. Luo, et al., "COVID-19: Challenges to GIS with Big Data," Geography and Sustainability, 2020/03/20/ 2020.

[14] Y. Yang, F. Peng, R. Wang, K. Guan, T. Jiang, G. Xu, et al., "The deadly coronaviruses: The 2003 SARS pandemic and the 2020 novel coronavirus epidemic in China," Journal of Autoimmunity, vol. 109, p. 102434, 2020/05/01/ 2020.

[15] R. Djalante, J. Lassa, D. Setiamarga, A. Sudjatma, M. Indrawan, B. Haryanto, et al., "Review and analysis of current responses to COVID-19 in Indonesia: Period of January to March 2020," Progress in Disaster Science, vol. 6, p. 100091, 2020/04/01/ 2020. 